\title{
A impossibilidade de indenização por dano moral pelo abandono afetivo de
}

menor

\author{
The Impossibility of Indemnification by Punitive Damages due to Minor Affective
}

Abandonment

\author{
Hammer Nayef Salman* \\ Adriana Fasolo Pilati Scheleder ${ }^{* *}$
}

\begin{abstract}
RESUMO: A pesquisa tem como objeto a possibilidade da aplicação do instituto da responsabilidade civil no abandono afetivo. No início da formação do grupo familiar o afeto não era considerado essencial, pois o foco era a proteção e a preservação do patrimônio. No decorrer da história, as relações afetivas foram tomando importância e a partir da Constituição Federal de 1988 o afeto familiar foi relacionado diretamente ao princípio da dignidade da pessoa humana recebendo caráter fundamental nas relações familiares. $\mathrm{O}$ afeto, porém, por vezes é negligenciado pelos genitores, fazendo com que a criança sofra abalo moral. $\mathrm{O}$ cerne da discussão encontra sua força ao se perquirir a possibilidade de indenizar-se pecuniariamente um filho que não teve o convívio devido com seu pai ou mãe. Tomando-se por base a pesquisa doutrinária e jurisprudencial, a pesquisa confronta duas teorias: a primeira que encontra sustentação na possibilidade da indenização por gerar um dano à integridade psicológica e moral da criança; a segunda se baseia na impossibilidade de se valorar o afeto ou a perda dele. Em que pese a importância do afeto na formação básica de uma criança, depreende-se que haja a impossibilidade da responsabilização por abandono moral. Por se tratar de matéria subjetiva e extrapatrimonial, não se pode mensurar um sentimento com exatidão. Além disso, não pode se confundir o dever de cuidar com o afeto. Enquanto aquele é previsto em lei e é uma obrigação; este é sentimento voluntário que não decorre de qualquer obrigação não sendo, portanto indenizável.
\end{abstract}

PALAVRAS-CHAVE: Abandono afetivo; Indenização; Responsabilidade Civil.

ABSTRACT: This research has as object the possible punitive damages due to emotional abandonment. At the beginning of the formation of the family group the affection was not considered essential because the focus was on the protection and preservation of heritage. Throughout history, emotional relationships started to receive attention and since the Brazilian Federal Constitution of 1988, the family affection has been directly related to the human dignity principle of that entitled as a fundamental character within family relationships. The affection, however, is overlooked by parents sometimes, causing the child to suffer moral distress. The core of the discussion finds its strength when it is necessary to assert the possibility to indemnify a child who did not have chance to live with his father or mother. Taking as a basis legal writings and jurisprudence, the research confronts two theories: the first finds support in the possibility of compensation for punitive damages due to distress of the psychological integrity and morel of a child; the second is based on the inability to value the affection or the loss of it. Despite the importance of affection in the basic formation of a child, it appears that impossible to impose liability for moral abandonment. Because it is subjective and not related to assets, you can not measure a feeling exactly. Also, you can not mistake the duty of care with affection. While that is provided for by law and is an obligation; this is a voluntary feeling that does not come from any obligation and therefore it cannot be object of compensation.

KEYWORDS: Affective Abandonment; Indemnity; Civil Responsibility.

\footnotetext{
* Bacharel em Direito pela Universidade Passo Fundo - RS. Pesquisador do Grupo Dimensões do Poder e Relações Sociais. E-mail: hammersalman@ @otmail.com.

${ }^{* *}$ Doutora em Direito pelo Programa de Pós-Graduação em Direito da Universidade Federal de Santa Catarina. Mestra em Direito Processual Civil pela Pontifícia Universidade Católica do Rio Grande do Sul. Pesquisadora do Grupo Dimensões do Poder e Relações Sociais. Professora e Coordenadora Adjunta do Mestrado em Direito da Universidade de Passo Fundo - RS. E-mail: apilati@upf.br.

Data de recebimento do artigo: 05/02/2016 - Data de avaliação: 10/02/2016 e 12/02/2016.
} 


\section{INTRODUÇÃO}

A presente pesquisa cientifica tem como objeto de estudo a responsabilidade civil por descumprimento dos genitores do dever legal de cuidar e manter a prole em convívio familiar. A investigação questiona a possibilidade de fixação de indenização por danos morais no caso de abandono afetivo da prole, pelos seus genitores.

Muito se tem discutido acerca da questão, principalmente nos dias atuais, em que os direitos das crianças estão cada vez mais relevantes. A partir da Constituição Federal de 1988, houve uma revolução no ordenamento jurídico, direitos e garantias foram elevadas resultando em um novo conceito de família baseada no princípio da dignidade da pessoa humana.

Com o advento da Constituição Federal de 1988 somado ao Estatuto da Criança e do Adolescente, Lei n 8.069 de 13 de julho de 1990 e também do Código Civil de 2002, a família deixa de ser vinculada a característica patrimonialista e se embasa no afeto e nas pessoas que compõem o grupo, assegurando à criança direito à vida, saúde, educação, cultura, dignidade e convivência familiar.

A Lei Maior promoveu uma alteração radical no quadro das relações familiares, mediante a introdução determinados princípios, que modificaram todas as legislações ordinárias daí provenientes. Os antigos princípios do Direito de Família foram aos poucos sendo abarcados pela constitucionalização do direito de família, remodelando esse ramo jurídico.

A Constituição Federal de 1988 promoveu, assim, uma verdadeira revolução social quebrando paradigmas e dando uma particular atenção aos direitos e garantias individuais. Partindo da supremacia dos princípios da dignidade da pessoa humana, se alastrando no princípio da afetividade e solidariedade, foi possível englobar novas entidades familiares constitucionalizadas.

Desse modo, após a vigência da Constituição Federal as famílias adquiriram novos contornos, seguindo-se do princípio da pluralidade familiar, tendo sido reconhecidos novos vínculos afetivos como entidade familiar.

A solidariedade social é adotada como objetivo fundamental da República Federativa do Brasil e visa buscar a constituição de uma sociedade livre, justa e solidária. O princípio da solidariedade tem reflexos nas relações familiares, pelo fato de ser um elemento que deve existir nesses relacionamentos pessoais.

Tal princípio serve de base para o amparo da guarda socioafetiva na medida em permite 
a um menor de idade conviver em um ambiente familiar repleto de afetos e responsabilidades, compartilhando experiências e saberes interdisciplinares, que acabam por contribuir para o seu crescimento.

A solidariedade familiar, apesar de pouco evidenciada na legislação, é algo essencial desde os primórdios e foi o que tornou possível a sobrevivência e progresso do homem, pois, serviu para fortalecer vínculos e acompanhar a evolução humana.

A pesquisa, portanto, preocupa-se com a possibilidade ou não de responsabilização parental referente ao abandono afetivo, quando o desamparo não garante ao filho a chance de desenvolvimento moral e psicológico, danificando assim sua educação e seu caráter. Por meio do método dedutivo, a controvérsia será analisada diante o ordenamento jurídico pátrio, tendo em vista a constitucionalização do direito de família.

Por fim, terá destaque o abandono afetivo no ordenamento constitucional e o tratamento do problema pela doutrina nacional e pelos tribunais na atualidade. $\mathrm{O}$ assunto é relevante e merece um estudo mais aprofundado, pois o tema clama por uma solução.

\section{ABANDONO AFETIVO NO ORDENAMENTO CONSTITUCIONAL E CIVIL}

O direito de família, por se tratar de relações entre pessoas, envolve afinidades extremamente subjetivas, versando sobre a afetividade entre os componentes, o que torna a ocorrência de danos morais e atentados à dignidade da pessoa humana muito comum.

No grupo familiar há muitos atritos que dão vazão a lesões extrapatrimoniais as quais não podem ser esquecidos. Desta forma o artigo 229 da Constituição Federal enseja a ocorrência de possíveis lides envolvendo relações familiares. ${ }^{1}$.

A família não deve ser posicionada como uma entidade forasteira pelo Estado. Deve sim ser destinada a tal entidade todas as garantias individuais e a aplicação das normas gerais da responsabilidade civil, pois quando um membro familiar vem a causar dano, atinge um interesse extrapatrimonial do outro.

Salienta-se que a lesão gerada por um membro familiar a outro é mais grave do que é provocado por terceiro externo à relação interna da família, "visto que pelo que a lesão é maior devido a situação de privilégio que o ofensor detém, por pertencer ao núcleo familiar, justificando a aplicação da responsabilidade civil.”. (CARDIN, 2012, p. 183).

\footnotetext{
${ }^{1}$ Art. 229. Os pais têm o dever de assistir, criar e educar os filhos menores, e os filhos maiores têm o dever de ajudar e amparar os pais na velhice, carência ou enfermidade.
} 
Mediante a constitucionalização da família, se elevou a um patamar de grande valia, o qual trouxe a valorização do instituto e se deu início aos cuidados com o vínculo de afetividade e solidariedade entre os indivíduos componentes e passou-se a exigir responsabilidade entre esses entes por atos danosos cometidos em detrimento dos outros.

A atual tendência do ordenamento jurídico e especialmente do direito de família é de construir uma vida individual e social digna, baseada no cumprimento dos deveres e direitos morais e afetivos, destacando-se a importância do respeito mútuo, nas relações entre pais e filhos, crianças e adolescentes. Isso quer dizer que o ideal a ser alcançado em todas as relações familiares é a harmonia, por meio da prática do afeto.

Em se tratando de proteção ao direito e à personalidade de filhos menores deve-se ter uma atenção especial. Afirma-se que ofende a dignidade da pessoa do filho não apenas a ausência de socorro patrimonial, mas também a omissão no apoio moral e psicológico. O abandono intelectual do pai ou mãe com relação a filho menor gera traumas que resultam em dano moral. É, pois, evidente que uma reparação nunca restabelecerá ou fará brotar o amor e o afeto, mas é uma conotação que implica em indenização por danos morais. (VENOSA, 2012, p. 300).

É fundamental a presença positiva dos pais na educação e formação dos filhos. A relação familiar não se desenvolve de forma plena sem a presença de um dos pais:

\begin{abstract}
a ligação simplesmente biológica ou genética não sustenta por si só a família. Como se enfatiza, toda problemática da família gravita em torno da proteção à dignidade humana. Assim, por exemplo, na teoria tradicional há um direito de visitas do progenitor separado, mas não há obrigação de visitas. A recusa ou omissão nas visitas, mais modernamente, é aspecto que pode gerar indenização. [...] O direito de família posiciona a família como célula básica da sociedade e fundamento do interesse do Estado, destacando como centro desta célula, "a preservação do ser humano e sua formação humana integral", tutelando e responsabilizando a dignidade e o afeto nas relações familiares. (ARAUJO, 2010).
\end{abstract}

Portanto, nas situações em que se constatando o afastamento do pai, ou da mãe, ou de ambos deste centro, a ausência precisa ser bem avaliada em suas particularidades, para efeitos de danos e consequências os demais membros familiares principalmente para os filhos.

Como se percebe, a legislação acompanha o que acontece na realidade, ou seja, assim como em todas as relações familiares regidas, o afeto recebe cada vez mais destaque nos estudos atuais. Com isso a família deixa de ser baseada apenas por laços sanguíneos e por presunções e passa a levar o sentimento afetivo consigo.

Dessa forma, o relacionamento apropriado entre pais e filhos, sejam estes parentes biológicos ou não, é presumido por um relacionamento de afeição. Esta relação que deve 
A impossibilidade de indenização por dano moral pelo abandono afetivo de menor

garantir a prole pleno desenvolvimento saudável, garantindo saúde, educação, dignidade e convivência familiar, entre outros direitos observados que deverão ser garantidos na relação paterno-filial.

Ao abandonar seu filho, o genitor estaria negligenciando seus deveres podendo causar a seu filho traumas psíquicos impossíveis de serem reparados e difíceis de serem abrandados com o tempo, dispondo a legislação civil a respeito do Direito de Família de procedimento próprio para punir os genitores desobedientes de tais garantias, sendo este a aplicação de pensão alimentícia.

Entretanto, fundando-se no princípio do afeto, da dignidade da pessoa da responsabilidade familiar, os filhos que foram vítimas de do abandono afetivo têm buscado judicialmente indenização por seus genitores pelo dano moral causado pela falta de afeto e do convívio na sua formação.

Deve-se frisar, entretanto, que existem limites impostos pela legislação no que diz respeito ao abandono afetivo, e é sobre isso que será tratado no capitulo a seguir.

\subsection{A responsabilidade civil no abandono afetivo}

O afeto é um sentimento abstrato, especialmente para o direito, no qual é aplicado de maneiras diversas, mas com semelhante embasamento, qual seja relacionamento interpessoal.

Pode ser utilizado para fundamentar uma decisão, mas esse fundamento vai estar maculado pelo pensamento do juiz que não é isento de sentimentos carregados durante sua vida.

Para compreender melhor a temática, é imprescindível que se defina o que é o abandono afetivo. Depreende-se que este nada mais é do que a atitude nula do pai ou da mãe no cumprimento dos seus deveres em nível moral decorrentes do poder familiar, dentre os quais se destacam os deveres de prestar assistência moral, educação, atenção, carinho, afeto e orientação à prole tal como previsto no artigo 22 da Lei n. 8.069 de 1990.

Para os doutrinadores Tartuce e Simão "o afeto talvez seja apontado, atualmente, como o principal fundamento das relações familiares". (2013, p. 22). Mesmo não fazendo parte a expressão afeto da Carta Magna como sendo um direito fundamental, pode-se afirmar que ele deriva da relevância da dignidade humana.

O Direito escolta a mentalidade da sociedade, e com o instituto do afeto não foi diferente. É manifesto que em outros tempos o afeto era nulo, completamente esquecido pela 
lei, mas atualmente isso tem mudado, como se pode perceber com o advento da Constituição da República e seus artigos 226 e 227 já mencionados.

Os direitos dos filhos encontram-se resguardados constitucionalmente sob a forma de princípios anteriormente estudados dando prioridades à criança e ao adolescente. Assim, quando vem à tona o estudo da afetividade e responsabilidade depara-se com várias correntes. Algumas dando procedência a possibilidade de indenização por falta de afeto. Outras, por se tratar de assunto subjetivo e inquantificável se colocam contra a possibilidade de reparação do dano.

Também têm sido fonte de demandas judiciais casos de abandono afetivo dos pais em relação a seus filhos dentre os inescusáveis deveres paternos figura o de assistência moral, psíquica e afetiva, e quando os pais ou apenas um deles deixa de exercitar o verdadeiro e mais sublime de todos os sentidos da paternidade, respeitosamente a interação do convívio e entrosamento entre pai e filho, principalmente quando os pais são separados, ou nas hipóteses de famílias monoparentais, em que um dos ascendentes não assume a relação fática de genitor. (MADALENO, 2013, p. 382).

Com a separação dos pais, ou mesmo quando estes nunca conviveram juntos, levando em conta deveres concernentes ao poder familiar, permanecem inalterados. É inegável, porém, que muitos pais relaxam no cuidado de seus filhos, atentando-se apenas para o dever de pagar uma pensão alimentícia, abandonando-os ao acaso.

Porém como se trata de pressuposto subjetivo, deve-se antes de julgar superficialmente, perquirir sobre o suposto abandono. É incontestável que a situação de negligência pode e deve causar aos filhos transtornos psicológicos aos filhos. Porém, este estudo se propõe a adentrar na parte que se refere, principalmente, a questionar esse abandono.

Sob o fundamento do princípio da dignidade da pessoa humana, da afetividade e da solidariedade, as vítimas de abandono afetivo têm ingressado judicialmente com o escopo de serem indenizadas civilmente por seus pais pelos danos psicológicos causados pela falta do afeto e do convívio na sua formação.

\subsection{Deveres dos genitores na formação dos filhos}

A família, sob uma visão constitucional, carrega características afetiva e solidária, propensa a promover a ampliação da individualidade e o respeito aos direitos fundamentais de seus membros. A afetividade toma um lugar de destaque, no qual integrantes da família, em tese, devem sentir-se acolhidos e amparados. 
A impossibilidade de indenização por dano moral pelo abandono afetivo de menor

No tocante às relações entre pais e filhos, o afeto encontra abrigo na previsão constitucional do direito a dignidade, da solidariedade e da afetividade. Estes, aliás, devem ter direito a uma atenção especial, pois são seres humanos com personalidade em desenvolvimento.

\begin{abstract}
De fato, o afeto depende de condições para sua efetivação e realização, e é a convivência que permite que estes vínculos se desenvolvam e saiam do plano da subjetividade individual para construir a intersubjetividade. Daí a importância tão grande que deve ser atribuída à convivência, que atende um direito da personalidade do menor, e encontra-se positivada tanto na Constituição Federal, quanto no Estatuto da Criança e do Adolescente e nas questões relativas à guarda dos filhos menores (GROENINGA, 2010).
\end{abstract}

No entanto, deve-se ter cuidado quando se interpreta a palavra "conviver", pois nos dias atuais é comum a separação e divórcio dos pais, sendo que este vocábulo deve ser interpretado de modo mitigado. Não representando apenas o estar perto no sentido restrito da palavra.

O poder familiar revela-se como a mais importante condição existente na relação familiar. Este coloca a afetividade responsável no mais alto patamar que liga pais e filhos. Este poder facilita o encontro entre ambos, pelo carinho, enfim, pela vivência familiar. A importância do afeto no ordenamento jurídico encontra-se exemplificada no artigo $28, \S 2^{\circ}$ do Estatuto da Criança e do Adolescente $^{2}$, que disciplina o pedido de colocação em família substituta, momento em que pai ou mãe devem agir em prol dos filhos, de forma exemplar, de modo a garantir o respeito e a proteção recíproca.

\begin{abstract}
O conceito atual de família, centrada no afeto como elemento agregador, exige dos pais o dever de criar e educar seus filhos sem lhes omitir o carinho necessário para a formação plena de sua personalidade, como atribuição do exercício do poder familiar. A grande evolução das ciências que estudam o psiquismo humano veio a escancarar a decisiva influência do contexto familiar para o desenvolvimento sadio das pessoas em formação. Não se podendo mais ignorar essa realidade, passou-se a falar em paternidade responsável. [...] A missão constitucional dos pais, pautada nos deveres de assistir, criar e educar os filhos menores, não se limita a vertentes patrimoniais. (DIAS, 2009, p. 415).
\end{abstract}

Ser pai ou mãe exige disposição para educar, disciplinar, conviver e respeitar. A paternidade, segundo Dias, "é função na qual se insere a construção do amor paterno-filial, cuja base é o desenvolvimento físico, mental, moral, espiritual, cultural e social da pessoa em

\footnotetext{
${ }^{2}$ Art.28 Na apreciação do pedido levar-se-á em conta o grau de parentesco e a relação de afinidade ou de afetividade, a fim de evitar ou minorar as consequências decorrentes da medida.
} 
formação". (2011, p. 117). O término do vínculo dos genitores segundo o autor, não é capaz de alterar as relações entre pais e filhos, permanecendo incólume a responsabilidade parental.

O questionamento que também se faz ao abordar o assunto é se estas medidas não acabariam por recompensar o genitor infrator, "prejudicando e deixando sem resposta a questão da reparação civil por abandono, pois como já se viu aos filhos em formação é de fundamental importância o convívio saudável com seus genitores, o afeto, o sentimento de acolhimento". (MADALENO, 2010).

No entanto, esta responsabilização civil por abandono afetivo é divergente na jurisprudência e na doutrina, pois muitos estudiosos referem que a indenização por abandono não causaria o efeito de reaproximar pais e filhos, inexistindo, assim, resultados efetivos, pois na legislação pátria não existe o dever jurídico de amar.

\section{ABANDONO AFETIVO NAS RELAÇÕES FAMILIARES NOS DIAS ATUAIS}

A afetividade adquiriu grande importância por parte da legislação, gerando tumultuadas discussões. Assim, as pessoas passaram a procurar o cumprimento de uma obrigação por negligência da afetividade. De tal forma, todos passam a procurar o cumprimento do lado afetivo, aparecendo uma triste realidade que é o abandono afetivo. É um tema de certa forma novo, assim, está, ainda, sem regulamentação específica na lei. Mas como definir esse abandono?

\footnotetext{
O abandono moral é tão prejudicial como o abandono material, ou até mais, afinal a carência de recursos materiais pode ser superada através do trabalho árduo do outro genitor, o afeto não pode ser substituído, a sua ausência pode destruir princípios morais, principalmente quando estes ainda não estão consolidados na personalidade da criança e do adolescente. (COSTA, 2008).
}

Nem sempre a responsabilidade parental é bem compreendida, fazendo com que muitos pais se afastem de forma intencional dos filhos após a separação do casal, negligenciando os deveres de assistência moral, psíquica e afetiva. Mesmo nas situações em que a relação dos genitores nunca existiu, muitos pais livram-se afetivamente seus filhos, sem exercer o direito de visitas, que na verdade deveria ser o dever de visitas, causando prejuízos em sua criação.

Dentre os inescusáveis deveres paternos figura o de assistência moral, psíquica e afetiva, e quando os pais ou apenas um deles deixa de exercitar o verdadeiro e mais sublime de todos os sentidos da paternidade, respeitante a interação do convívio e entrosamento entre pai e filho, principalmente quando os pais são separados ou nas hipóteses de famílias monoparentais, onde um dos ascendentes não assume a relação 
fática de genitor, preferindo deixar o filho no mais completo abandono, sem exercer o direito de visitas, certamente afeta a higidez psicológica do descendente rejeitado. (MADALENO, 2013, p. 310)

Diversas circunstâncias podem caracterizar a negligencia moral. Alguns pais acreditam que, custeando os filhos por meio de pensão alimentícia, seja plenamente suficiente para se eximir da responsabilidade em manter uma relação socialmente aceitável.

Percebe-se, em todas estas situações, o traço marcante do abandono afetivo, que consiste no descaso intencional pela criação, educação e convívio com os filhos, podendo ser nefasto para o desenvolvimento destas crianças. (MADALENO, 2010).

Sobre as consequências da conduta de pais negligentes, Gomide constata que a "negligência é considerada um dos principais fatores, senão o principal, a desencadear comportamentos antissociais nas crianças". (2004).

É certo, portanto, que o afeto e o convívio e afeto com os pais são importantes para o bem estar das crianças em formação.

\subsection{Posicionamentos doutrinários e jurisprudenciais contrários ao dever de indenizar}

Os doutrinadores que combatem a aplicação da teoria da responsabilidade civil no direito de Família temem que "o pai condenado à pena pecuniária por sua carência será um pai que nunca tornará a se aproximar daquele filho, em nada contribuindo o pagamento da indenização para restabelecer o amor”. (COSTA, 2008).

Neste sentido decidiu o Tribunal de Justiça do Rio Grande do Sul ao reconhecer a inocorrência de abandono afetivo, entendendo que a responsabilidade civil no direito de família é assunto subjetivo. ${ }^{3}$

A inteligência dessa corrente, portanto, leva a crer que a procedência de indenização poderia trazer malefícios a relação entre genitor e filho.

A pura e simples violação do afeto não deve ser motivo para ensejar uma indenização por dano moral, pois somente quando uma conduta caracteriza-se como ilícita, é que será possível falar-se em indenização pelos danos dela decorrentes, sejam eles materiais ou morais. Para o autor, reconhecer a indenizabilidade decorrente da negativa do afeto produziria uma verdadeira patrimonialização de algo

\footnotetext{
3 “A responsabilidade civil no Direito de Família é subjetiva, de modo que o dever de indenizar pressupõe o ato ilícito e nexo de causalidade. Nesse passo, não se pode reconhecer como ato ilícito o alegado abandono afetivo que, por sua vez, não guarda nexo de causalidade com os danos alegadamente sofridos pela autora". (RIO GRANDE DO SUL, TRIBUNAL DE JUSTIÇA, Apelação Cível nº 70054827019, Oitava Câmara Cível, Rel. Alzir Felippe Schmitz, j. em 26 set. 2013).
} 
que não possui tal característica econômica, subvertendo a evolução natural da ciência jurídica, retrocedendo a um período em que o ter valia mais do que o ser. No entanto, o mesmo autor pondera que, em que pese a negativa de afeto entre pai e filho não dê ensejo a uma indenização por dano moral, devendo-se utilizar os mecanismos dispostos pelo Direito de Família para a solução do caso, é possível que este abandono enseje um dano material, por exemplo, quando desta negligência advier traumas que demandam tratamento psicológico. Nestes casos o dano é tão somente de ordem patrimonial, gerando uma indenização, com base no ressarcimento integral (restitutio in integrum). (FARIAS; ROSENVALD, 2010).

Desta forma, a posição negativa do dever de indenizar por falta de afeto defende que os deveres decorrentes da paternidade ou maternidade não podem adentrar na subjetividade, pois não há obrigação legal de amar.

O Tribunal de Justiça de Minas Gerais, no julgamento da Apelação Cível $\mathrm{n}^{\circ}$ 1002407790961-2, apoiou a inteligência de que a omissão afetiva dos pais não caracteriza ilícito por inexistir obrigação de dedicar amor. ${ }^{4}$

No mesmo sentido, o Tribunal de Justiça de São Paulo, em julgamento da Apelação $\mathrm{n}^{\circ}$ 0004614-77.2009.8.26.0634, negou indenização por abandono afetivo, sob o fundamento de que este não caracteriza ilícito, bem como não cabe ao Judiciário adentrar nas questões de cunho sentimental, pois o carinho não se impõe, se conquista ${ }^{5}$.

Nas relações familiares, segundo seguidores deste veio jurisprudência, compete ao Judiciário a defesa dos direitos fundamentais, sem interferência em lides de cunho emocional, pois a imposição de pagamento não seria resposta para alcançar o carinho e a aproximação pretendida. Tavares da Silva entende que

[...] não é falta de amor em si que acarreta a obrigação de indenizar, e sim o preenchimento dos requisitos da responsabilidade civil nestes casos, quais sejam: descumprimento intencional e injustificado dos deveres dos genitores de educar e ter os filhos em sua companhia, ou seja, o desrespeito ao direito destes à convivência familiar, além do nexo entre esta omissão ou negligência e o dano comprovado à figura dos filhos através de perícia. (2011)

Portanto, a corrente prenuncia que não há qualquer irregularidade proveniente de pai ou

\footnotetext{
4 “A omissão do pai quanto à assistência afetiva pretendida pelo filho não se reveste de ato ilícito por absoluta falta de previsão legal, porquanto ninguém é obrigado a amar ou a dedicar amor. Inexistindo a possibilidade de reparação a que alude o art. 186 do Código Civil, eis que ausente o ato ilícito, não há como reconhecer o abandono afetivo como passível de indenização". (BRASIL, TRIBUNAL DE JUSTIÇA DE MG, Apelação Cível no 1002407790961-2, $12^{\circ}$ Câmara Cível, , Rel. Des. Alvimar de Ávila, j. 11 fev. 2009, DJ 13 jul. 2009).

5 “Alegação de abandono afetivo. Teoria de responsabilidade civil que não se consubstancia em ato ilícito elemento indispensável para caracterização do dever de indenizar. Impossibilidade obrigacional. Afeto é sentimento incondicional. Precedente do Colendo Superior Tribunal de Justiça”.(SÃO PAULO, TRIBUNAL DE JUSTIÇA, Apelação Civil nº 0004614-77.2009.8.26.0634, Rel. Des. Coleho Mendes, j. 05 abr. 2011, DJ 20 abr. 2011).
} 
mãe não destinar afeto a um filho.

Outro fundamento contrário à indenização é a cogitação que se faz sobre os efeitos práticos da condenação, pois a intenção primordial do direito atual é buscar soluções não litigiosas para os conflitos.

A indenização por abandono moral deve estar amparada em lei e não apenas ser presumida. Ademais, o quantum indenizatório se mostra de difícil fixação a partir da premissa de que o bem a ser tutelado é totalmente abstrato.

\subsection{Posicionamentos doutrinários e jurisprudenciais favoráveis ao dever de indenizar}

Para esta corrente seguida por autores como Madaleno e Dias, subsistem razões para divergir da corrente que nega a reparação pela omissão do afeto, pois a indenização nestes casos não tem mais nenhum desígnio de impelir o restabelecimento do amor, mas visa reparar o irreversível prejuízo causado ao filho que sofreu pela ausência de seu pai ou de sua mãe, já não mais existindo amor para recuperar. ${ }^{6}$

Dias entende que "a omissão do genitor em cumprir os encargos decorrentes do poder familiar, privando seu filho do convívio paterno, pode produzir danos emocionais merecedores de reparação" (2009, p. 416).

A Ministra Nancy Andrighi, no Recurso Especial nº 1.159.242 - SP (2009/0193701-9) entendeu não existem restrições legais à aplicação das regras concernentes à responsabilidade civil e o consequente dever de indenizar. Para Dias, "comprovado que a falta de convívio pode gerar danos, a ponto de comprometer o desenvolvimento pleno e saudável do filho, a omissão do pai gera dano afetivo susceptível de ser indenizado”. (2009, p. 416). No mesmo sentido, tem-se o ensinamento de Stoco:

[...] o que se põe em relevo e insurge como causa de responsabilização por dano moral é o abandono afetivo, decorrente do distanciamento físico e da omissão sentimental, ou seja a negação de carinho, de atenção, de amor e de consideração, através do afastamento, do desinteresse, do desprezo e falta de apoio e, às vezes, da completa ausência de relacionamento entre pai (ou mãe) e filho. (2007, p. 946.).

\footnotetext{
6 “A condenação ao pagamento de indenização, em decorrência do abandono paterno, é possível, desde que cabalmente demonstrados os requisitos ensejadores da responsabilidade civil, ou seja a omissão paterna, o dano e o nexo de causalidade. Na hipótese, o réu somente soube ser pai do autor por meio de ação de investigação de paternidade, ajuizada quando o filho já contava com 25 anos de idade. Por outro lado, os laços afetivos são construídos ao longo de muitos anos de convivência, e não com a prolação de um provimento jurisdicional. $\mathrm{O}$ autor não logrou demonstrar o aventado dano que sofreu, não se desincumbindo do ônus probatório, nos termos do artigo 333, inciso I, do Código de Processo Civil”. (SÃO PAULO, TRIBUNAL DE JUSTIÇA, Apelação nº 91077933020098260000, Rel. Fabio Podestá, j. em 30 jun. 2015, DJ 01 jul. 2015).
} 
De acordo com estudiosos que se coadunam com esta teoria estabelecem requisitos para que se indenize:

\begin{abstract}
Desta forma, estabelecida exata correlação entre o afastamento paterno e o desenvolvimento de sintomas psicopatológicos no filho, comprovado o comprometimento da sua saúde física e psicológica em razão do eventual fracasso do laço paterno, é passível falar-se de indenização o abandono afetivo com fulcro no princípio da dignidade da pessoa humana, cuja previsão encontra guarida no art. $1^{\circ}$, III da Carta Magna. Tal indenização se justificaria pela previsão de que todo cidadão tem o dever de ressarcir eventual dano causado a outrem com a sua conduta voluntária e consciente, responsabilidade esta prevista nos arts. 186 e 187 do Código Civil de 2003. Nesta acepção, restringir este afeto, omitindo-se diante de uma paternidade ou maternidade, inviabilizando a convivência entre pai/mãe e filho, constitui abuso de direito. (MADALENO, 2010).
\end{abstract}

Os defensores desta posição julgam que o caráter é punitivo e preventivo na reparação de danos, ou seja, o pai ou mãe deverá ter ciência do dano e devem prevenir-se de que sua conduta de abandono deve ser cessada e evitada.

Apesar de posicionar-se favorável à reparação, Nader pondera que: "seriam raros na prática os casos de sucesso, pois o ônus de todas as provas seria do lesado, a quem caberia comprovar o dano, a conduta nociva e o nexo, que se revela de difícil comprovação caso as lesões tenham sido de natureza psíquica.” (2010, p. 365).

A responsabilização civil seria uma forma de forma de compensar este sofrimento e punir o genitor infrator, além de alertar os demais genitores para as consequências destes atos.

Assim, o abandono afetivo, segundo alguns, é passível de indenização desde que provado o dano à integridade física, intelectual e moral dos filhos, bem como a conduta ofensiva e o nexo de causalidade.

\title{
3 ANÁliSE SOBRE A POSSIBILIDADE INDENIZAÇÃo DOR ABANDONO AFETIVO
}

Pelo estudo realizado, portanto, amparado na doutrina e jurisprudência chega-se a conclusão de que a indenização por dano afetivo não tem o escopo de compelir os pais à execução de seus deveres afetivos, nem de reaproximar os laços existentes entre pais e filhos.

As principais leis existentes para a proteção das crianças são a Constituição Federal e o Estatuto da Criança e do Adolescente, porém, como bem enfatizam Medeiros e Goulart, 
[...] é possível perceber que ambas as leis impõem obrigações inerentes à sobrevivência e à formação de caráter da criança. $\mathrm{O}$ afeto, por sua vez, não é inerente à sobrevivência. Tal sentimento é importante para a formação do caráter por ser um facilitador, um meio melhor da criança compreender muitas lições de vida que seus genitores passam, contudo não é o único. $\mathrm{O}$ afeto se distingue do princípio da solidariedade familiar, na medida em que o princípio da solidariedade familiar seriam os deveres que os familiares têm entre si, e o afeto seria o meio para cumprir estes deveres. (2015).

O valor a ser pago não mudará a relação já vigente, pois nenhum pai ou mãe começará a dar assistência moral simplesmente porque está pagando uma indenização.

Com esta ação reparatória, o filho não busca o amor que nunca recebeu, e sim, dinheiro pelo abandono sofrido, que supostamente lhe causou danos que precisariam ser ressarcidos. Pode-se dizer que busca um pagamento carregado de ressentimentos e ódio a ser reforçado pelo ingresso da ação judicial.

Não se reconhece a ocorrência do dano afetivo visto que o amor e o carinho não são exigíveis do ponto de vista obrigacional, conforme destaca o Desembargador Marcus Túlio Sartorato do Tribunal de Justiça de Santa Catarina: “os sentimentos compreendem a esfera mais íntima do ser humano e, para existirem, dependem de uma série de circunstâncias subjetivas. Portanto, o filho não pode obrigar o pai a nutrir amor e carinho por ele, e por este mesmo motivo, não há fundamento para reparação pecuniária por abandono afetivo" (SANTA ATARINA, TRIBUNAL DE JUSTIÇA, AC n 292381, . Rel. Des. Marcus Túlio Sartorato. j. 30 jun 2010).

Também já se manifestou o Tribunal de Justiça do Estado do Rio Grande do Sul, por meio do Desembargador André Luiz Planella Villarinho afirmando que "a paternidade pressupõe a manifestação natural e espontânea de afetividade, convivência, proteção, amor e respeito entre pais e filhos, não havendo previsão legal para obrigar o pai visitar o filho ou manter laços de afetividade com o mesmo. Também não há ilicitude na conduta do genitor, mesmo desprovida de amparo moral, que enseje dever de indenizar". (RIO GRANDE DO SUL, TRIBUNAL DE JUSTIÇA. Apelação Cível no 70044341360, Sétima Câmara Cível, Rel. André Luiz Planella Villarinho, j em 23 nov. 11 2011).

Percebe-se que as leis que amparam as crianças impõem obrigações inerentes à sobrevivência e à formação de caráter. Aponta-se que o afeto interfere diretamente no comportamento, sem, no entanto ser decisório, pois pode ser compensado por outros membros familiares ou pessoas próximas que tenham afinidade com a criança.

$\mathrm{O}$ afeto, por mais triste que possa parecer, não é inerente à sobrevivência. Tal sentimento, não se nega, é importante para a formação do caráter por ser um facilitador, um 
meio melhor de a criança compreender muitas lições de vida que seus genitores passam, contudo não é o único. $\mathrm{O}$ afeto não se mescla dentro do princípio da solidariedade familiar, na medida em que este princípio aponta para os deveres que os familiares têm entre si. $\mathrm{O}$ afeto seria o meio para cumprir estes deveres, ou seja, pelo o que se pode perceber nas decisões dos Tribunais confundem-se o dever de cuidado com o afeto.

Em que pese a Terceira Turma do Tribunal de Justiça de São Paulo, Recurso Especial n. 1.159.242 - SP (2009/0193701-9), tenha entendido que é possível exigir indenização por dano moral decorrente de abandono afetivo pelos pais, afirmando ainda que "amar é faculdade, cuidar é dever", discorda-se dessa afirmação, pois se amar é faculdade não existe obrigatoriedade, e se não existe obrigatoriedade não existe dever de indenizar.

Convém ressaltar que o que enseja reparação é o descumprimento do dever jurídico de conviver com o filho e não a falta de afeto por si. É, neste sentido, a lição de Lira, ao dispor que

[...] o dever dos pais em conviver com os filhos não está relacionado, apenas, com as questões afetivas, embora estas sejam extremamente importantes nas definições acerca da convivência. Tal dever está também relacionado com a paternidade/maternidade responsáveis, previstas no art. 226 da CF, assim como, está por que não acrescentar, ao direito fundamental da criança e do adolescente. (2010, p. 550).

Entende-se, pois, pela impossibilidade da reparação civil por abandono afetivo, pois a reparação pecuniária poderia provocar uma monetarização ou banalização do amor.

A simples indenização representa um caráter meramente punitivo, sem repercussões positivas no bem estar psicológico da criança. Uma compensação em dinheiro por algo que não teve e nunca terá.

É dificultoso cogitar-se a possibilidade de determinada pessoa postular amor em juízo, visto que a capacidade de dar e de receber carinho faz parte do íntimo do ser humano, necessitando apenas de oportunidades para que aflore um sentimento que já lhe faz parte, não podendo o amor, em que pese tais conceitos, sofrer alterações histórico-culturais, ser criado ou concedido pelo Poder Judiciário. (SCHUH, 2006, p. 67-68).

A preocupação com o abandono deveria centrar-se, como já citado, com o dever de convivência e não tratar deste como um direito. Não se quer dizer, que a convivência seja restrita ao contato físico, já que muitos pais se separam ou nem chegam a viver juntos, mas do concreto acompanhamento dos filhos afim de realmente exercer o dever do poder familiar 
O afeto não é decorrente do vínculo genético. Se não houver a tentativa de aproximação de ambos os lados, a relação entre pai e filho estará predestinada ao fracasso. A relação afetuosa deverá ser fruto de aproximação espontânea cultivada reciprocamente, e não de força judicial. Exceto em casos extremos não vejo razão para o reconhecimento do dever de reparação. Após a lide, uma barreira intransponível os afastará ainda mais, sepultando qualquer tentativa futura de reconciliação. Se a solução para o problema fosse o dinheiro, a própria pensão alimentícia atenderia ao objeto de reparação, o que não ocorre. Quanto ao efeito, dissuasório e punitivo, corremos o risco de mal ainda maior, como foi dito anteriormente. (CASTRO, 2008, p.15).

Acerca do dever de cuidado é importante lembrar que "para os pais que não cumprem o dever de cuidado, em respeito ao princípio da solidariedade familiar, há o instituto da pensão alimentícia". Esta, conforme o autor, "tem justamente o propósito de obrigar ao genitor a cumprir com o dever de cuidado para com o menor abrigando nesse valor, possíveis danos psicológicos gerados pela falta do pai ou da mãe”. (MEDEIROS; GOULART, 2015).

Entende-se, com isso, que permitir a indenização seria complicar ainda mais o instituto da pensão alimentícia já implementada. Deve o juiz simplesmente analisar danos, já que a pensão pode ser revista a qualquer momento e majorar valores de acordo com o que está sendo pleiteado.

O voto do ministro Massami Uyeda, vem ao encontro da tese da impossibilidade de aplicação de indenização por gerar consequências devastadoras após a separação. Além disso, traz a tona possibilidade de ações carregadas de má-fé:

\footnotetext{
Ora, se atentarmos para a realidade dos fatos, qualquer filho, qualquer filha, enfim, qualquer pessoa poderá dizer assim: mas estou sendo preterido em relação aos meus irmãos e qualquer dado subjetivo poderia motivar um pedido de indenização por dano moral. Ora, isso faria com que quantificássemos ou potencializássemos as mágoas íntimas - muitas legítimas, algumas supostamente legítimas - de filhos, de irmãos, de pais, de marido e mulher também, porque o dever dos cônjuges está entre prestar assistência, amar e tal. E os estudos indicam que esse amor é uma coisa da convivência. O que pode acontecer nesse nível de família? Quando a situação se torna de tal maneira insustentável, separação de fato, separação judicial, divórcio. E alguém dizer que, além disso, quer o dano moral porque não foi tratado condignamente como esposa, como marido, ou, então, neste caso, como filha. (BRASIL SUPERIOR TRIBUNAL DE JUSTIÇA, Resp. n 2009/0193701-9. Rel: Min. Nancy Andrighi 2015).
}

Assim, com base nos fundamentos expostos, infere-se não ser possível a aplicação de indenização por danos materiais em razão da falta de afeto, visto que, como demonstrado anteriormente, para que se aplique o instituto da indenização pelo dano moral, é necessário que haja dano por ato ilícito. 


\section{CONCLUSÃO}

As opiniões doutrinárias e jurisprudenciais acerca da viabilidade ou não da responsabilidade civil por abandono afetivo, como visto no decorrer do estudo, são divergentes. Duas correntes travam uma grande batalha de opiniões, nesse campo.

A primeira manifesta-se favorável às reparações pecuniárias, uma vez comprovada a existência do dano moral utilizando, tendo como argumentos o princípio constitucional da dignidade da pessoa humana, o princípio da afetividade, dentre outros. Os estudiosos afirmam que o valor pecuniário compensaria a perda amorosa e o abandono moral.

A segunda, de modo contrário, defende a impossibilidade de reparação pecuniária na seara do desamparo moral, uma vez que é impossível ressarcir o amor não revelado de modo incondicional.

Ao analisar as duas formas de entendimento expostas acima, conclui-se a adesão pela segunda corrente pelos motivos que a seguir se passa a expor.

Depreende-se que, na maioria das vezes, essa indenização apenas servirá como uma forma de atenuar o sofrimento não funcionando como reparação, até porque é impossível obrigar alguém a dedicar carinho e afeto. O amor imposto de forma obrigatória pode ser, em muitos casos, ainda mais nocivo que o abandono. O medo de pagamento de uma indenização poderá gerar um pai presente, porém prejudicial à criança, atrasando seu desenvolvimento psicológico.

O afeto é uma faculdade e deve ser recíproco, precisando ser um caminho de mão dupla. Muitas vezes, encontram-se filhos que não respondem ao afeto dos pais, fazendo com que estes se afastem, e, por isso, não podem estes ser penalizados. Se a solução para o problema fosse o dinheiro, este poderia estar incluso na própria pensão alimentícia.

Além disso, a força deste entendimento recai sobre a ideia de que desde que seja fornecido tudo o que for imprescindível para o crescimento físico e intelectual do menor, em outras palavras, a partir do momento em que o genitor cumpre com o dever de cuidado, não há que se falar em indenização por falta de afeto. Mesmo que haja o dano causado pela tristeza da ausência de um pai ou mãe, que, muitas vezes, não compartilha seu tempo com o filho ou segue sua vida formando nova família.

$\mathrm{Na}$ visão atual, depreende-se que ante tantas mutações familiares, torna-se quase impossível não haver danos afetivos. Isso não quer dizer que se deve banalizar o afeto, dando procedência a pedidos de dano moral, muitas vezes decorrente do próprio estilo de vida e das 
relações modernas.

Não se discute aqui o dano causado, por óbvio, tal abandono vai causar prejuízos à personalidade do indivíduo abandonado moralmente por seu genitor. Pode-se trazer, entretanto, à discussão questões em que o afastamento do pai é indispensável para o bem estar da criança.

Se for considerado, por exemplo, em um pai ou mãe usuário de drogas ou violento, questiona-se com veemência a condenação por abandono, pois essa seria ainda mais prejudicial à saúde física e mental da criança. A relação nunca assumiria a plena capacidade de forma juridicamente aceita e socialmente aprovada, pois, nestes casos, o próprio abandono seria favorável ao desenvolvimento do menor.

Ao mesmo tempo, pode-se trazer a tona a questão da compensação do afeto negado por genitores ser suprido por outros entes familiares como avós ou tios, ou, ainda, o amor despendido por outrem fora do âmbito considerado familiar. O que interessa, afinal, é o afeto em si, que deveria, de forma natural, ser oferecido pelos pais, porém, muitos são os casos desse afeto provir de outras pessoas senão os genitores.

Adicionando e seguindo a tese proposta por essa pesquisa, entende-se que mesmo tendo sido comprovado judicialmente o abandono proposital, é possível recorrer ao pedido da revisão da pensão alimentícia, pois esta pode ser majorada para, por exemplo, um tratamento psicológico. O instituto da pensão alimentícia, por certo simplificaria o problema, já que possui função de, primeiramente, garantir as necessidades básicas da criança como alimentação, moradia, vestuário, educação e lazer e, além disso, visa a manter a saúde mental da criança, mesmo após a separação.

Ante a impossibilidade de se quantizar tal tipo de dano, ainda tem-se a dificuldade na configuração ou prova deste, na medida em que toda separação carrega consigo um sentimento ruim de ódios e rancores. O cônjuge que fica com a guarda da criança, de forma consciente ou não, utiliza, em muitas ocasiões, os filhos como meio de vingança pessoal. Desta forma, o Judiciário não pode ser instrumento de manipulação por ex-cônjuges, deixando a criança a mercê de brigas externas.

Assim, por todos os argumentos expostos, conclui-se pela impossibilidade de indenização por desamparo moral, pois a aplicação desta não alcança a função social pretendida e não demonstra qualquer finalidade positiva em sua aplicação para o menor abandonado afetivamente. 


\section{REFERÊNCIAS}

ARAUJO, Ana Paula Valentim. Consequências Jurídicas do abandono afetivo: responsabilidade civil. Disponível em: <http://www.jus.com.br/artigos/35918 > Acesso em: 16 jul. 2015

BRASIL. Superior Tribunal de Justiça. Resp. n. 2009/0193701-9. Relatora: Nancy Andrighi. 24-04-2012. Disponível em: <https://ww2.stj.jus.br/revistaeletronica/ita.asp?registro=200901937019> Acesso em: 10 out. 2015.

Constituição Federal da República Federativa do Brasil. Disponível em: <http://www.planalto.gov.br/ccivil_03/Constituicao/Constituicao.htm.> Acesso em: 12 out. 2015.

Código Civil de 2002. Lei n. $^{\circ} 10.406$, de 10 de janeiro de 2002. Disponível em: <http://www.planalto.gov.br/ccivil_03/Leis/2002/L10406.htm>. Acesso em 12 out. 2012.

Estatuto da Criança e do Adolescente. Lei n 8.069, de 13 de julho de 1990. Disponível em: <http://www.planalto.gov.br/ccivil_03/Leis/L8069Compilado.htm.> Acesso em: 12 out. 2015.

CARDIN, Valéria Silva Galdino. Dano Moral no Direito de Família. São Paulo: Saraiva. 2012 .

CASTRO, Leonardo. O preço do abandono afetivo. Revista IOB de Direito de Família, Ano IX. n. 46. fev./mar. 2008, p. 14-21.

COSTA, Maria Isabel Pereira. A responsabilidade civil dos pais pela omissão do afeto na formação da personalidade dos filhos. Revista Jurídica, Porto Alegre, ano 56, n.368, p.45-70, junho, 2008.

DIAS, Maria Berenice. Manual de direito das famílias. 4. ed. rev. atual. e amp. São Paulo: Revista dos Tribunais, 2007.

Manual de direito das famílias. 5. ed. rev. atual. e amp. São Paulo: Revista dos Tribunais, 2009.

FARIAS, Cristiano Chaves de; ROSENVALD, Nelson. Curso de Direito Civil: direito das famílias. 4. ed. Salvador: JusPODIVM. 2010.

GOECKS, Renata Miranda; OLTRAMARI, Vitor Hugo. A possibilidade do reconhecimento da união estável putativa e paralela como entidade familiar frente aos princípios constitucionais aplicáveis. In: MADALENO, Rolf; MILHORANZA, Mariângela Guerreiro 
(Coord.). Atualidades do direito de família e sucessões. Sapucaia do Sul: Notadez, 2008.

GOMIDE, Paula Inez. Pais presentes pais ausentes: regras e limites. Petrópolis: Vozes, 2004. GROENINGA, Giselle Câmara. A função do afeto nos contratos familiares. In: Afeto e Estruturas Familiares, Coordenadores: Maria Berenice Dias, Eliene Ferreira Bastos e Naime Marcio Martins Moraes, Belo Horizonte: Del Rey, 2010.

LIRA, Wlademir Paes de. Direito da Criança e do Adolescente à convivência familiar e uma perspectiva de efetividade no Direito Brasileiro. In: Família e responsabilidade: Teoria e Prática do Direito de Família. Coord. Rodrigo da Cunha Pereira. Porto Alegre: Magister/IBDFAM, 2010.

MADALENO, Rolf. A multa afetiva. 2010. Disponível no site:<http://www.ibdfam.org.br/?artigos\&artigo=52.> Acesso em 04 jul. 2015.

O dano moral no direito de família. In: COUTO, Sergio. SLAIBI FILHO, Nagib.

Responsabilidade civil: estudos e depoimentos no centenário do nascimento de José de Aguiar Dias (1906-2006). Rio de Janeiro: Forense, 2006.

Curso de direito de família. 5 ed. rev., atual. e ampl. Rio de Janeiro: Forense, 2013. MEDEIROS, Arthur Henrique Magalhães; GOULART, Leandro Henrique Simões. Da impossibilidade de pleitear indenização por falta de afeto. Disponível em <http://npa.newtonpaiva.br/letrasjuridicas/?p=513> Acesso em: 16 out. 2015.

MINAS GERAIS. Tribunal de Justiça de Minas Gerais. Apelação Cível $\mathrm{n}^{\circ}$ 1002407790961-2, $12^{\circ}$ Câmara Cível do TJMG, Rel. Des. Alvimar de Ávila, j. 11.02.2009, DJ 13.07.2009. Disponível em: <http://www.tjmg.jus.br/portal/jurisprudencia/consulta-dejurisprudencia/> Acesso em: 15/10/2015.

NADER, Paulo. Curso de Direito Civil: Responsabilidade Civil. Rio de Janeiro: Forense, 2010, v. 7.

SÃO PAUlO. Tribunal de Justiça de São Paulo. .Apelação Civil no 0004614 77.2009.8.26.0634, $10^{\circ}$ Câmara de Direito Privado do TJSP, Rel. Des. Coleho Mendes, j. 05.04.2011, DJ 20.04.2011. Disponível em: https://esaj.tjsp.jus.br/cjsg/resultadoSimples.do;jsessionid=B32AA2E074AD7094FED03CC8 D238D816.cjsg1 ?nuProcOrigem $=$ n\%C2\%BA+0004614-77.2009.8.26.0634\&nuRegistro=, Acesso em: 15.10.2015.

RIO GRANDE DO SUL. Tribunal de Justiça do Rio Grande do Sul. Apelação Cível Nº 70044341360, Sétima Câmara Cível, Tribunal de Justiça do RS, Relator: André Luiz Planella Villarinho, Julgado em 23/11/2011. Disponível em:< www.tjrs.jus.br/jurisprudencias $>$. 
Acesso em: 15/10/2015.

STOCO, Rui. Tratado de Responsabilidade Civil. Doutrina e Jurisprudência 7. ed. São Paulo: Revista dos Tribunais, 2007.

SCHUH, Lizete Peixoto Xavier. Responsabilidade civil por abandono afetivo: a valoração do elo perdido ou não consentido. Revista Brasileira de Direito de Família, Porto Alegre: Síntese, v. 8, n. 35, abril/maio 2006, p. 67-68.

TARTUCE, Flávio; SIMÃO, José Fernando. Direito Civil: Direito de Família. Rio de Janeiro: Forense; São Paulo: Método, 2013, v. 5

TAVARES DA SILVA, Regina Beatriz. Caso real de abandono paterno. 2011. Disponível em <http://www.reginabeatriz.com.br/academico/artigos/artigo.aspx?id=203>. Acesso em $10 / 09 / 15$

VENOSA, Silvio de Salvo. Direito civil: responsabilidade civil. 12. ed. São Paulo: Atlas, 2012, v. 4. 